\title{
綜說 \\ 日本人の無機質摄取量 \\ On the Average Intake of Minerals for Japanese
}

\author{
久保彰治 \\ (Shoji Kubo)
}

戦後十年以上を経過して，日本人の食噃事情はすでに 常態復したと考えてよいであろ5。しかしなお，日本 人に不足している栄緟素は，カルシウムとビタミン $\mathrm{B}_{2}$ で あるといわれる。ここ数年, カルシウムの栄養学的意義 についての研究か，本誌をはじめ各㻎雑誌の紙面をにぎ わしており，それらの報交によつても，日本人のカルシ ウム不足は決定的であると思われる。

これまで栄数調査の基楚资料となつていた，昭和25年 版日本食品漂準成分表(1)は，その数值，ことに Ca，P， $\mathrm{Fe}$ の值か，実際と著しくちがつていることか，多数の 研究者によつて指摘されるに至り，やかて昭和29年，こ の表は全面的に改訂されだ2。この改訂の主カの一つ か， $\mathrm{Ca}, \mathrm{P}, \mathrm{Fe}$ の数值の改正にあてられたので，すくな くともこれら無機質に関しては，成分表は相当信頼する にたると考えられた。

厚生省昭和 30 年国民栄㾞調查の成續か；前年と比較し て，娒と鉄の掑取量は大幅に減少し，カルシウムは総量 に执いてはあまり变化していないか，その内容に捄いて 全く変貌しているのは，この政訂新表によつたためであ る。

一方，栄善調査の成續もしくは，成分表から計算した 掑取量か，実際の食慨中の $\mathrm{Ca}, \mathrm{P}, \mathrm{Fe}$ 量とかなりの差 のあることは，常に指摘されているところで，両者の比 较を行つた研究すまたすくなくない。この問題はここの 新らしい成分表を用いた場合すなお完全海消せず，あ たかす，成分表にはそれなりの限界があるかのよ5な印 象をすら与えている。

しかし、ビタミンやアミノ酸とことなり，無機質のよ 5 K，分解して無くなることのない栄養素について，成 分表からの計算值と，実際の分析值か一致し得ないこと は，本当にやむを得ないすのであろらか。われわれは今 すこしこの問題を再检討する必要があろら。けたし， 無機質の計算值と分析值は，一致するのが当然で，一致 してこそ正しい揁取量の概念が得られるはずたからであ る。

本稿炕拈いて筆者は，この不一致の間題にふれつつ， 日本人のカルシウム，梏，鉄の掑取量を論じ，あわせて
筆者か行ないつつある実験からすいくつかの事揍を引き たして，2，3の考察をこころみたい。

はたしてCaはどれたけ不足かままた Pは過剩か，Fe は十分か。それは決して簡単な問題ではない。「掑取 だけでそれに答えることは，きわめて不分であろらが， 吸収，代謝，要求量等の問題に介入するのは，筆者のよ くなしらるところではない。

また近年, 高単位ビタミン郕に各種の無機塩類を加え た、いわゆるミネラル大りビタミン郕がわか国です発売 され，かなりの普及度を示している。これら㙁類の中に は、銅、マンガン等の微量金属もふくまれており，それ らについてははつきりしたデータがすくなく，特に日本 人の掑取量についてはわずかな報告しかない。薬品のパ ンフレットや，一部の著書は，多く外国のデータそのま まであり，中にはいちじるしく間違つたものさえある。

はたしてそれら微量ミネラル郕は，日本人の栄喥に必 要なのであろらか。そもそも日本人は，どれたけけ微量 ミネラルをどんな食品からとつているのか。そうした 問題についても，マンガン, 銅, 亜鉛の 3 元素を中心に, 2,3 の考察を行つて見よ5。

カルシウム・燐・鉄の摄取量

\section{1. 栄養部查の成柇}

諉論の基碟として，厚生省の行なつた昭和 30 年度国民

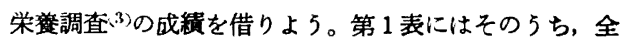
国年間平均 1 人 1 日あたりの掑取量を，昼品群別にあげ たるのを揭げた。

国民栄養調查の成績は，いろいろなかたちでまとめら れて㧍り，全国平均のほかに，6大都市，農村，水座業 地区，林業地区等，多数のブロ，ク别掑取栄誉量が揚げ られている。Ca，P，Feに関しては、これらの間に特記 すへきき差は見られず，Ca 掑取量か冬季にいくらか多く なつている傾向もビタミンAに拈けるごとくはつきり したすのではない。

さて，椇取栄養をことあらたに論ずるまであなく，

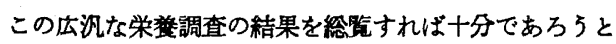
は，碓しも考えることにちがいない。その場合，Ca 338 
第 1 表 厚生省・昭和30年国民栄貝調查 全国平均 ( 1 人 1 日当)

\begin{tabular}{|c|c|c|c|c|c|}
\hline & & $\begin{array}{c}\mathrm{g} \\
\mathrm{g}\end{array}$ & \begin{tabular}{cr} 
カ & \multicolumn{1}{c}{} \\
シゥムム \\
mg
\end{tabular} & $\begin{array}{l}\text { 燐 } \\
\mathrm{mg}\end{array}$ & $\begin{array}{l}\text { 鉄 } \\
\mathrm{mg}\end{array}$ \\
\hline 棇 & 量 & $1,100.2$ & 338 & 1,373 & 14 \\
\hline 款類 $\begin{cases}\text { 米 } & \\
そ & の\end{cases}$ & 他 & $\begin{array}{l}346.6 \\
133.0\end{array}$ & $\begin{array}{l}21 \\
31\end{array}$ & $\begin{array}{l}541 \\
226\end{array}$ & $\begin{array}{l}2 \\
2\end{array}$ \\
\hline 堅 & 類 & 0.4 & 3 & 2 & 0 \\
\hline$w$ & 類 & 80.8 & 13 & 32 & 0 \\
\hline 砂 & 類 & 15.8 & 7 & 3 & 0 \\
\hline 脂 & 類 & 4.4 & 0 & 0 & 0 \\
\hline 豆類 $\left\{\begin{array}{l}\text { 味 } \\
\text { 大豆 製 } \\
\text { その他の豆 }\end{array}\right.$ & 豆 & $\begin{array}{r}2.1 \\
28.8 \\
29.4 \\
7.0\end{array}$ & $\begin{array}{r}4 \\
29 \\
50 \\
6\end{array}$ & $\begin{array}{l}11 \\
57 \\
36 \\
29\end{array}$ & $\begin{array}{l}0 \\
2 \\
1 \\
1\end{array}$ \\
\hline 魚介類 $\{$ 生 & 物 & $\begin{array}{r}67.8 \\
9.4\end{array}$ & $\begin{array}{l}32 \\
41\end{array}$ & $\begin{array}{l}151 \\
113\end{array}$ & $\begin{array}{l}2 \\
1\end{array}$ \\
\hline 獸 鸟 肉 & 類 & 12.0 & 1 & 25 & 0 \\
\hline 卵 & 類 & 11.5 & 7 & 27 & 0 \\
\hline 乳及び乳製 & 品 ! & 14.2 & .18 & 15 & 0 \\
\hline 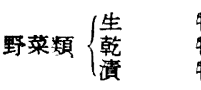 & 物 & $\begin{array}{r}190.5 \\
1.4 \\
54.3\end{array}$ & $\begin{array}{r}71 \\
1 \\
2\end{array}$ & $\begin{array}{r}69 \\
1 \\
28\end{array}$ & $\begin{array}{l}2 \\
0 \\
0\end{array}$ \\
\hline 実 & 類 & 44.3 & 6 & 8 & 0 \\
\hline 藻 & 類 & 4.3 & - & - & - \\
\hline 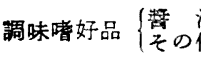 & & $\begin{array}{l}29.6 \\
12.8\end{array}$ & - & $\begin{array}{l}- \\
-\end{array}$ & - \\
\hline
\end{tabular}

$\mathrm{mg}, \mathrm{P} 1.37 \mathrm{~g}, \mathrm{Fe} 14 \mathrm{mg}$ というのが, その解答になる。

しかしながら，熱量やたんぱく質等とことなり，無機 質の撕取量については，現在の栄養調査の方法と結果の 解釈に，いくつかの問題があるよ5に思われる。いわば

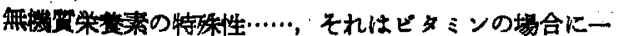
部相通ずるが，大かたはまつたく別䡛のものと考えられ る。以下そろしたことを中心に考えてみたい。

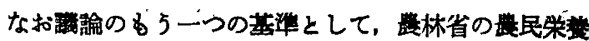

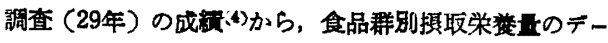
タの一部を借りて，第2表に揭げた。

なおこの調査では，琼類の数量全部に，加重平均 178 $\mathrm{mg} / 100 \mathrm{~g}$ を乗じて，P の算出を行つているが，この方

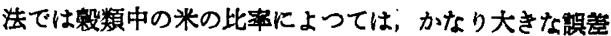
を生じ， P 摄取量の計算法としては不適当である。等者 はそのため，米のみ別に計算する方法で P を再計算して 別に揭げた。表中 P I. はもとの数値， P II. は䈉者の換 算值である。

P の例として全国平均のほかに，北陸蕰区のものを揭， げたのは，北陸地方か渄常に米に対する依存度が高く，

これか後述の P 掫取量の問題に大きくひびいてくるから である。

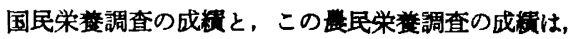
碞村の部について，毎年かなりの不一致を示している。

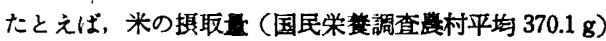
の差などは，决して小さなるのではない。これは，調查 対象にもずれがあるし，国民栄兴調查が1日 1 日の献立 をもとにしているのに対し，震民栄警調査が1日ないし 1 月の消费量に基碟をおいていることが，大きな原因の 一つであろらかと思われる。このことは栄諘調査そのす のにひそむ根本間題を呈示していると考えられるが，無 機質の攝取総骷においては，さして大きなひらきになつ ていない。

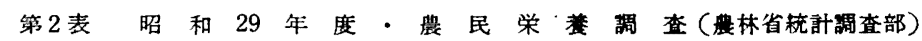

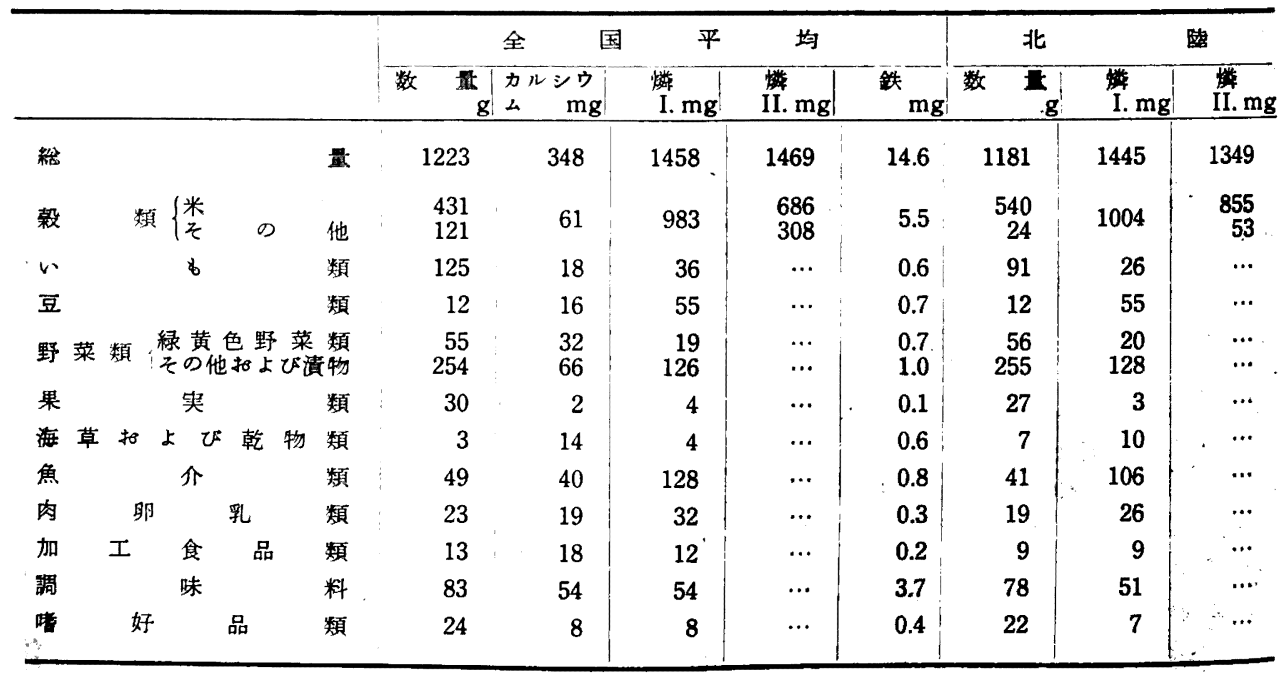


したがつて，不台理なことではあるが，一凩箬者は， この双方を正しいるのと仮定して考えをすすめたい。

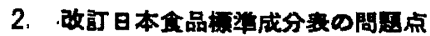

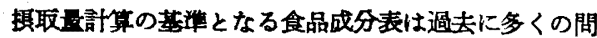
題を残した。現在の成分表は，も5不偖のないるのであ ろ5か。

第1龱 年饮別摄取量の变化

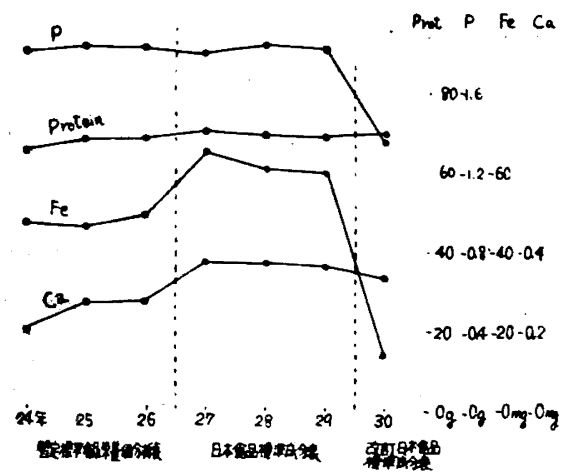

第 1 区に，国民栄調查年次別成害をグラフで示した。 図の如く, 昭和 26 年と 27 年, 昭和 29 年と 30 年の間

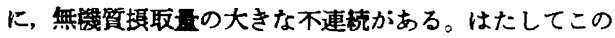
年に急激な栄䔲状態の变化がおこつたのであろらか。た んぱく質その他の例からこの考えは简単に否定される。 この不連航は，実にその年から「成分表か改訂された」 ためにほかならない。無挠質の栄養摄取量は，昭和30年 に至つて，はじめて正しい姿を示したといえよ5。しか し，ひるがえつて考えれば，その都度椇取量にこのよう な大变化をきたす程の, 大改訂を必要とした成分表か， 今後の改訂によつて, 再び摄取量の計算を狂わせてしま 5ことが絶対にないといえるであろ5か。

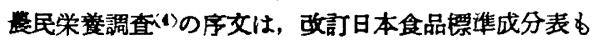
「なお内容的に多くの間通をふくんでいる」とのぺてい る。

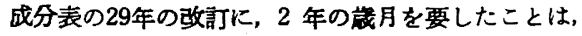
そかが根本的大欧訂であつたことの証左ともなろ5。原 实食㫛成分小委員長のもとに，欧訂の最大部が無機質の データの改正にあてられ，等者す無機質部門の一人とし て，それにたずさわつたことであつた。各委員の努力の 結果，すくなくとす成分表は面目を一新して，よ5ゃく 国際的にす見おとりのしない体裁をるつようになつたと 信じている。しかし，改訂の作莱にあたつては，無機質 に閣する限り，それまでの数值がまちがつていることは わかつていても，それ代代正しいデータははなはだ

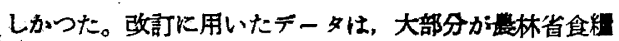

研究所と，厚生省栄瞇研究所において，改打前数年間に 分析された数值のみによるほかはなかつた。日本の全国 各地から，あらゆるデー夕を集樌する努力が十分でなか つたこともあろう。しかし，それにもまして「信頼し得 る」データはすくなかつたのである。

笵者の研究室では，成分表改妤の数年前から，日本食 品の $\mathrm{Ca}, \mathrm{P}, \mathrm{Fe}$ 含豉を測定してきた。それらのデータ は，表の改訂を急ぐのあまり，中途半端にまとめて，で きるたけ政予表にとりいれた結果，決して満足なるのと いえなかつた。策者はその後も分析を重ね，上うやく食 品の無譏会会の全貌に近づきつつある。やがてその結 果は順をおつて発表したいか，それらにてらしても，な お現在の表の数值にはかなりの誤りがあることを否定し 得ない。

第 3 表にそ5した一例を乾魚介類について揭げてみ た。魚介類をはじめとする水应食品のデータの不備は,

第3 表 乾魚介類の成分表估と分析値の 比校 $(\mathrm{mg} \%)$

\begin{tabular}{|c|c|c|c|c|}
\hline & \multicolumn{2}{|c|}{ 成 分 } & \multicolumn{2}{|c|}{ 分 析 表 } \\
\hline & $\mathrm{Ca}$ & $\mathrm{P}$ & $\mathrm{Ca}$ & $\mathbf{P}$ \\
\hline \multirow{3}{*}{ K ほ } & 970 & 2000 & 2490 & 1910 \\
\hline & & & 2280 & 1870 \\
\hline & & & 2760 & 2040 \\
\hline いわし生はし & 170 & 330 & 430 & 500 \\
\hline いわし丸ほし & 390 & 2000 & 860 & 690 \\
\hline はぜつくだに & 610 & 860 & 1760 & 980 \\
\hline ふなかんろに & 910 & 220 & 1900 & 1040 \\
\hline \multirow{2}{*}{$\begin{array}{lll}\text { 千 あ み } \\
\text { しば }\end{array}$} & 670 & 940 & 1820 & 1060 \\
\hline & 25 & 400 & 120 & 210 \\
\hline
\end{tabular}

現在の成分表の最弱点であり，上例などもその一つであ る。しかし無機質会量のあやまりは，水库食品のみなら ず，钤類，豆類，肉類，野菜類等全般にわたつて，随所 に存在する。

ただ幸いにす，それらのうち，無機筫含量のすくない

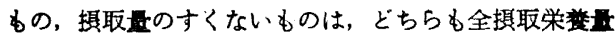
にほとんどひびいてこない。したがつて，成分表の数值 のちがいが全掫取量に影蠁するのはどんな食品か，また

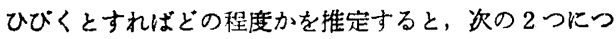
きるよ5である。

(i ) 骨ごとたべる魚介類, 乾魚, 甲款類では， P, Fe に大差なく，Ca は一般に今の倍程度になる。つくたに 類の多くは似た傾向をるつ。これらはおしなへて乾魚介 類の項にはいる。Ca $20 \mathrm{mg}$ 程度のブラスになろ5。

（ii）野菜㜔物の無機質か;成分表に記载のないるのが 
多く、ために淬物からの $\mathrm{Ca}, \mathrm{P}$ 掑取量が過少に評過さ れている。Ca $10 \mathrm{mg}, \mathrm{P} 20 \mathrm{mg}$ 程度のブラスになる。 成分表になお多数の欠陮があるにもかかわらず，Ca， $\mathrm{P}, \mathrm{Fe}$ の平均掑取量算出の結果にそれほどの差を生じて いないのは，しあわせである。改訂日本食品捧㔼成分表 は,すくなくとすその程度まで信頼してよいわけである。

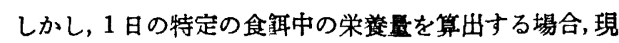
在の表ははなはだ心細いものであることに変りはない。 成分表の再改訂は，やはり急がなければならない。

\section{3. 栄㕠調查の計真から除外されている食品}

国民栄養調查では，調坤著好品および海草類を栄笭素 量計算からはぶいてある。（亚民栄笭調查はこれらを計 算にいれている。）無機留についてこれは正当な方法で はない。量的にはわずかであるが、これらは次のよ5に 掑取量に加算すべきであろ5。

(i) 調玙皆好品この5ち，しょ5油は完全な無機 質源となり，この最は無視できない。Ca $15 \mathrm{mg}$, P 50 $\mathrm{mg}, \mathrm{Fe} 1 \mathrm{mg}$ のプラスになる。蓉好品等の中には, 時

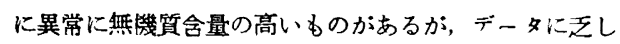
く、いまのところ無視するほかない。

(ii) 海草類は当然その消化吸収率が閴となる(则を $25,6,7$ 。海草中のカルシウムは吸収㔼が非常に悪いが,

0ではない，P, Fe についてはデータがほとんどないか， 海草中の P が大部分水溶性であるのに, Fe は非常に溶 けにくいことから，両者つ大体の消化難易を维論できそ 5である。海草の非常に高い無機筫含量から，すくなく とも Ca $10 \mathrm{mg}$ をプラスする必要があろ5。Feは 0 と 仮定し，P を計算すると䄪 $5 \mathrm{mg}$ となるが、これはPの 全摄取量に比し，ほとんど意味はない。

\section{4. カルシウム給源としての钦料水}

栄養調查には，飲料水の量はすち万んあげられてない。 しかしカルシウムに関する限り，水は忘れてならない栄

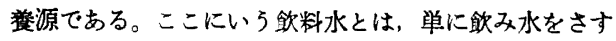
だけでなく，米をたく水，味曾汁の水，煮物の水なと， あらゆる調理用水をふくむ，水の摃取量は，体重，労作 状態，季節等によつてかなり異なり，また食事の内容に

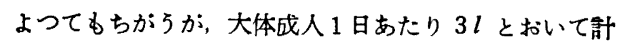
算しょ5。

领料水は河川水もしくは地下水によるものが大部分で あるがこの中には $100 \mathrm{cc}$ あたり 1〜数· $\mathrm{mg}$ の Ca が ふくまれるのが普通である。わが国の陸水は，きわめて 軟资なるのが多く， $\mathrm{Ca}$ 合量は概して低い。世界の河川 に比ぺて, $\mathrm{Mg} / \mathrm{Ca}$ 比が大きいことが特徵で, これはわ が国の地筫か，火成岩と第三紀層を主とすることによる らしい(8)。

河川水の分析例を第 4 表にあげた。都市の上水道はこ (226)

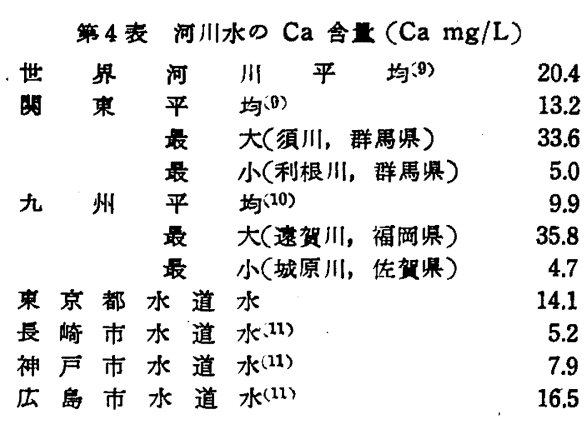

の河川水を処理するすのが多く，その $\mathrm{Ca}$ 含正はこれと 似たりよつたりである。るし $100 \mathrm{cc}$ 中に $1.5 \mathrm{mg}$ の $\mathrm{Ca}$ をふくむ水を $3 l$ とつたとすれば， 1 日の Ca は $45 \mathrm{mg}$ になり, 特に多い $3 \mathrm{mg} / 100 \mathrm{cc}$ のすのであれば, $90 \mathrm{mg}$ の Ca を水から椇取する計算になる。

井戸水は一般に河川水より $\mathrm{Ca}$ 含题が高く, $5 \mathrm{mg}$ 以 上の土地もまれではない。こ5した場合； 1 日に $150 \mathrm{mg}$ 以上の Caをとることになり，他からの摄取昷のなかば 近くに達する。

水の $\mathrm{Ca}$ は完全にイオン化しておりり, 吸収容易なこと わ留意すべきであろう。

水中の Ca は,かくてその土地固有の大きな差があり， それがおのずから Ca 撕取量の差になつている。長寿者 の多い村の井戸水に Ca が多かつたなどとい5例も，偶 然とのみいえないであろ5。

水中に $\mathrm{P} は$ ふくまれず, また $\mathrm{Fe}$ す極微量のことが普 通である。まれに Fe 掑取総量にひびく程の $\mathrm{Fe}$ を有す る水すあるか，水として要質なるのである。

水に関連して食㙁中の $\mathrm{Ca}$ のことす考えられるが，こ れは現在精彆度の高い食塩か厸く用いられる傾向にあ り，使用量からいつてあまり大きな一般的問題となり得 ない。

\section{5. 加工調理による主として燐の消畏}

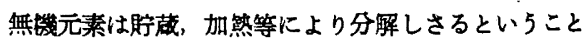
がないししたがつて原料食品が口にはいるまでの損失 は, あつぱら調理等に際して，水，煮汁などに無機筫が 溶出し，その液をすて去る場合のみにおこる。

国民栄䖭調査には，栄坦はすべて調理による損耗を 考凬していない，と記されてある。しかしこれはビタミ ンのことを主に指していると思われる。何故なら，無機 資の椇取基淮量の設定には，調理による損耗は考慮され てないからである。

一般に，食品を水洗したり，蒸劣したりすると，無㣪 㙁類の溶出損失をきたすといわれる。しかしその無㙨㙁 類とは Ca をさすのか，P をさすのか，あるいは全元荡 をまんべんなくさすのか,一向にはつきりしない。昭和 
初年の夈菜研究所報告は，食品の開理による成分变化の 広汎なデータをのせ， Ca, P, Fe についてす記戴がある。 しかし25年版罡準成分表の基碳となつたこの数值は，そ の後の研究により全面的に来却された。したがつてその 調理による变動率る，無機資に関してはまつたく意味を 失つた。この部門の解眀は再出発を余儀なくされたので ある。

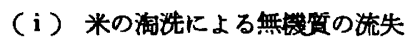

白米を水で䖲洗ナると $\mathrm{B}_{1}$ の損失があることはよく知 られている。しかし水洗による損失の最大なものは無機 资である。筆者の矢駼例を第 5 表に揭げた。これは簡単 に洗つた程度で，長時間かかつてとぎ上げると，この損 失はさらに增大する。この原因を，白米の表面に附着し ている糠の流亡に求めるのはあやまりで，これは米粒中 の水溶性成分か急速度で流出寸るからにほかならない。

第 5 表白米の成分浓出

\begin{tabular}{|c|c|c|c|c|}
\hline & \multicolumn{2}{|r|}{ 流 } & \multicolumn{2}{|c|}{ 出 $(\%)$} \\
\hline & 水 & 洗*3 回 & 1 夜 水 & 㖊** \\
\hline $\mathbf{K}$ & & 50 & & 58 \\
\hline $\mathbf{M g}$ & $\vdots$ & 53 & & 50 \\
\hline $\mathbf{P}$ & 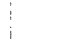 & 50 & & 45 \\
\hline $\mathrm{Fe}$ & $!$ & 54 & & 22 \\
\hline $\mathbf{M n}$ & $!$ & 33 & & 46 \\
\hline $\mathrm{Ca}$ & 1 & 23 & & 32 \\
\hline $\mathrm{Zn}_{\mathbf{n}}$ & & 10 & & 23 \\
\hline
\end{tabular}

* $100 \mathrm{~g}$ 第 1 回 $140 \mathrm{cc}$, 以後 $100 \mathrm{cc}$ ナっの水 で整く洗5。

** $100 \mathrm{~g} 250 \mathrm{cc}$ の水浸清。

表のごとく，P は $\mathrm{K}, \mathrm{Mg}$ とともに最高の溶出率を示 し，Ca は Zn とともに溶出量がすくない。別の米で行 つた実験すまつたく同じ㑯向を呈した。

日本人に過剩とされているPの，最大の給源である米 において，P の損失がはげしいことは看過できない。ま ず誰です最低 3 回性 5 として，白米のPの $50 \%$ はす でに水洗によつて失なわれることになる。したがつて実 際には，栄荃調査で算出された米からのPは，その半分 を差し引いて考えた方がよい。いまそれを栄 調査の 2,3の結果に適用すると(これまでのわずかな $\mathrm{P}$ 補正を 無視して) 第 6 表のよ

第6表 米のP損失を考点したP掫取量

\begin{tabular}{|c|c|c|c|c|c|}
\hline 民 & $\begin{array}{l}\text { 栄 } \\
\left\{\begin{array}{l}\text { 全 } \\
\text { 全 }\end{array}\right.\end{array}$ & & $\begin{array}{l}\text { 調 } \\
\text { 平 } \\
\text { 都 }\end{array}$ & $\begin{array}{l}\text { 查 } \\
\text { 均 } \\
\text { 市 } \\
\text { 村 }\end{array}$ & $\begin{array}{r}1102 \mathrm{mg} \\
995 \mathrm{mg} \\
1141 \mathrm{mg}\end{array}$ \\
\hline 民 & 栄 & 養 & 調 & 查 & \\
\hline & '全 & 国 & 平 & $\begin{array}{l}\text { 均 } \\
\text { 陸 }\end{array}$ & $\begin{array}{r}1126 \mathrm{mg} \\
921 \mathrm{mg}\end{array}$ \\
\hline
\end{tabular}

この結果から，従来いわれてきた，米を多くとるはど P がふえるとい5考えと逆に，実際に米にのみ依存して いる人ほど，P 撕取散がすくなくなる可能性のあること がわかる。事钅水洗損失を考虑した白米の $\mathrm{P}$ 含量 80 $\mathrm{mg} \%$ は，全食副の加重平均值をかなり下迴る值であ る。

ついでながら,このことは Mg についても同梯で, 白 米を高 $\mathrm{Mg}$ 食の代表とすることは必ずしもあたらない。

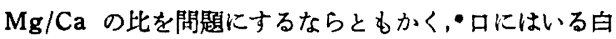
米の $\mathrm{Mg}$ は，小娄粉の場合より寸くないのである。

なお米はフィチン燐が多く，ために忣収をさまたげる といわれているか，実際の水洗によつて7割のフィチン 燐は溶出し、口にはいるフィチン橉はむしろ他の教類よ りすすくない。

$\mathrm{Ca}$ の流失は，流出率の低いのと，米自体の Ca 合豆 が低いため間題にならない。Fe の流失は一応計算にひ びく。しかし Feのこうした問題は, 後出の混入のヶー スにかくれて，やや意㼁がうすい。

(ii） 食品の無元素の移動性

米において，われわれはPが Ca よりよく水に溶出す ることをみとめた。食品にはいろいろの種類があり，そ の性質や，ふくまれる無機質の形態も多種多様である。 しかしそれら無機筫の調理による損失の傾向は，無機元 素固有の特性, いわば無機質の移動性のスタイルといつ たすのをあらわしていないであろらか。

筆者のこれまでの垁験によれば，米にあらわれた P> Ca の関保は，だいず，いんげんまめ，えんどう，こん ぶ,にんじん,さやいんげん, 茶, かれい, じやがいる の場合いずれも成立した。いんげんまめの例と，食品と はいい難いかむしれないがクロレラの例を揭げる（第7， 8 表)。

魚肉を水でさらすカマボコは，さらさないちくわより P 含责がはるかに低いし，また果実の罐詰でも，液汁中 にPの多くが溶けており，Ca はそれはどでない。

第7表 いんげん豆の成分溶出

\begin{tabular}{|c|c|c|c|c|c|c|}
\hline & \multicolumn{2}{|r|}{ 溶 } & 出 & \multicolumn{3}{|c|}{ 量 (\%) } \\
\hline & 水 & 浸* & 堂 & 沸** & 合 & 部 \\
\hline $\mathbf{K}$ & & 4.6 & & 9.0 & & \\
\hline Mg & & 4.3 & & 3.3 & & \\
\hline $\mathbf{P}$ & & 2.0 & & 7.1 & & \\
\hline $\mathbf{F e}$ & & 1.2 & & 1.2 & & \\
\hline $\mathrm{Ca}$ & & 1.6 & & 6.4 & & 0 \\
\hline Mn & & 0.7 & & 8.0 & & .7 \\
\hline
\end{tabular}

* $100 \mathrm{~g}$ を $400 \mathrm{ml}$ の水化1夜漫积。

** 不溶物を $400 \mathrm{ml}$ の水と意沸。 
第 8 表 Chlorella Ellipsoides の成分畨出

\begin{tabular}{|c|c|c|c|c|c|}
\hline & 含 量 & 溶 & 出 & \multicolumn{2}{|c|}{ 贵 (\%) } \\
\hline & $(\mathrm{mg} \%)$ & 水者沸* & 塩酸浸出**| & 合 & 幛 \\
\hline $\mathrm{K}$ & 1030 & 80 & 20 & & 100 \\
\hline $\mathrm{Mg}$ & 705 & 45 & 38 & & 83 \\
\hline$P$ & 1680 & 60 & 27 & & 87 \\
\hline $\mathrm{Fe}$ & 545 & 1 & 21 & & 22 \\
\hline $\mathrm{Ca}$ & 815 & 20 & 70 & & 90 \\
\hline $\mathrm{Mn}$ & 16 & 4 & 30 & & 34 \\
\hline $\mathrm{Zn}$ & 230 & 2 & 86 & & 88 \\
\hline $\mathrm{Cu}$ & 13 & 10 & 32 & & 42 \\
\hline
\end{tabular}

* $20 \mathrm{~g}$ を $500 \mathrm{ml}$ の水と意沸する。

** 水素沸不溶物を $0.2 \mathrm{~N}-\mathrm{HCl}$ K浸皘。

程度の羑, あるいはいくつかの例外はあろ5か，すく なくとも食品の $\mathrm{P}$ は $\mathrm{Ca}$ より水に溶けやすいと思われ る。したがつてPは米以外でもとかく調理による損失が あり、Ca はそれがすくないことになる。

实際の食邻について P を分析した多くの例が 1 日 $1 \mathrm{~g}$ $\sim 1.4 \mathrm{~g}$ 程度の結果を得ており，時には $1 \mathrm{~g}$ 以下を示し ている(网夫ば 10) のは，上記の考虑にもとつけば，納得の 行くことである。日本人の P 摄取量は決して多くない。

(iii) 清物における燐の增加

P の易動性による損失の例のみをあげたので，逆の例 にも一つふれておこ5。すなわちねか清けの場合, 棣中 に大量に存在寸る $\mathrm{P}$ は容易に野菜中に移行し, 清物の $\mathrm{P}$ はかなり大きな数值を示している。これはP 增大のはと んど唯一の例であるがこれについては寸でに 2-ii で ふれてある。

6. 拥理加エによる主として鉄の混入

鉄の調理器具から混入寸る Fe も栄餈調査にあらわれ ない。鉄鍋から Feが食品に混入するいちじるしい例は， 後藤氏の報文 ${ }^{(17)(18)}$ にくわしい。つくたに類が時に異常 な高 $\mathrm{Fe}$ 含量を示すのは，めつぱらこっした混入による あのであり，觹詰類も一般に原料食品より $\mathrm{Fe}$ が多くな つている。調理に鉄鍋を用いている場台は, 栄逢調査に あらわれたよりも，かなり多量の $\mathrm{Fe}$ を摄取しているこ とになろう。

たた最近は都会地はもらろん，地方でも鉄鍋は次第に 数すくなくなつておりこのヶースはまえはど普遍性を あたなくなりつつある。同時にいろいろな食品加工面 で，技術の進歩と注意により，Fe 混入は次第にすくなく なつており，成分表の $\mathrm{Fe}$ 量す，食品によつては年ごと に減らして行かねばならぬよ5な事態す考えられる。

- 食品は眅売, 輸送, 加工, 調理等のいろいろな段階に おいて，鉄に接触する埸台か渄常に多く，さまざまな不
湘の渖入の因となる。しかしそれらの混入 Feがすべて 吸収利用の対象となるかは、これまたはなはだあゃしい るのがある。溶出したのでなく，単に附荋した鉄さびな どか，化学分析ではすへて Fe として測定されることは, 逆に注意を要する。一般的には， Fe は栄蓄調査の数俌 を少し上迴るのが英状であろう。哭際の分析值す大体そ の辺を示している。

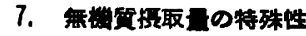

これまで等者は，栄曼調查の平均值を基準として編じ てきた。しかしここでわれわれは，一般成分とことなる 無譏䖪の特殊性をふりかえる必要があろう。一言にして いえば，その掑取量の大きな個人差である。

(i) 食品の $\mathrm{Ca}, \mathrm{P}, \mathrm{Fe}$ 合昰注打個体差

食品の無譏筫合量の個体差は，一般成分の域合上りは るかに大きいのが普通である。前述の敢料水の Ca 差は この一例であり, 加工食品における $\mathrm{Fe}$ 混入の多少す, 個体差の大きな一例であつた。

葉莱類の $\mathrm{Ca}$ 含量には，時に異常な差が出てくる。例 えば東京近庰産のかぶの葉の数值は, 第 9 表のよ5なひ ろがりを見せた。成長過程中の $\mathrm{Ca}, \mathrm{P}$ 含量の变化すま たすくなくない(19)。

一様にしらすぼしと呼ばれているものにも, おのずか ら稚魚の成長度の差が存在する。第 10 表の分析例のご とく， Ca 舍量は成長ととすに漸次增大し，P の增加に 先行する。 $\mathrm{Ca} / \mathrm{P}$ 比の增大は骨の成長を如実に示してい る。成分表の平均値と，目前の食品の栄素素量か，ど

第 9 表加ぶの莱の分析例

\begin{tabular}{|c|c|c|c|c|c|c|}
\hline & $\mathrm{Ca}$ & $\mathrm{mg} \%$ & $\mathbf{P}$ & $\mathrm{mg} \%$ & $\mathrm{Fe}$ & mg\% \\
\hline 1 & & 417 & & 65 & & 4.2 \\
\hline 2 & & 211 & & 17 & & 1.2 \\
\hline 3 & & 207 & & 39 & & 3.8 \\
\hline 4 & & 150 & & $54^{\circ}$ & & 4.5 \\
\hline 5 & & 114 & & 67 & & 2.3 \\
\hline 6 & & 110 & & 54 & & 4.5 \\
\hline 7 & & 105 & & 49 & & 3.4 \\
\hline 8 & & 54 & & 62 & & 1.6 \\
\hline
\end{tabular}

第 10 表 しらすほしの分析例

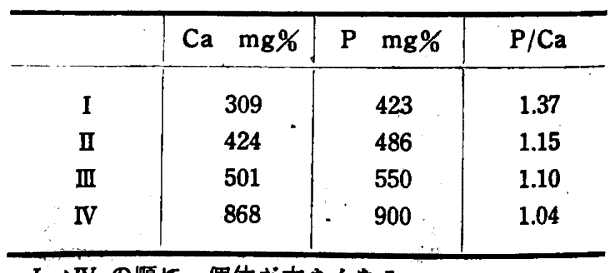

I $\rightarrow \mathrm{IV}$ の順K, 個体が大をくなる。 
の程度一政しているか虫，無機筫についての面要な，し かすはなはだ手のつけられない間題である。

さらに例をとうふに借りよ5。成分表によれば，と5 ふの Ca 会量は $170 \mathrm{mg} \%$ となつている。現在市販され ていると5ふは，以前のよ5ににがり $\left(\mathrm{MgCl}_{2}\right)$ を用い て整造するるのはすくなく，大部分がスマシ粉と称する $\mathrm{CaSO}_{4}$ によつて龄固が行われている。したがつて,と 5 ふの $\mathrm{Ca}$ の大小は, この $\mathrm{CaSO}_{4}$ かと 5 ふ中に捕捉され ることの多少にかかり、これは整造条件に大きく左右さ れる。第 11 表のごとく，と５ふおよび関連食品の分析 値は, Ca についてかなりの開きがある。

第 11 表と5s, 油あぼ, 厚あげの分析例 Ca mg\% P mg\%

\begin{tabular}{|c|c|c|c|c|c|}
\hline$\varepsilon$ & 5 & s. & $\left\{\begin{array}{r}251 \\
166 \\
136 \\
103 \\
45\end{array}\right.$ & $\left.\begin{array}{r}95 \\
91 \\
57 \\
102\end{array}\right\}$ & $\begin{array}{l}\mathrm{CaSO}_{4} \text { 使 } \\
\mathrm{MgCl}_{2} \text { 使 }\end{array}$ \\
\hline 油 & あ & げ & $\left\{\begin{array}{r}704 \\
287 \\
274 \\
99\end{array}\right.$ & $\left.\begin{array}{l}253 \\
204 \\
239 \\
280\end{array}\right\}$ & $\begin{array}{l}\mathrm{CaSO}_{4} \text { 使 } \\
\mathrm{MgCl}_{2} \text { 使 }\end{array}$ \\
\hline & ప & ஜ゙ & $\left\{\begin{array}{l}378 \\
267 \\
124\end{array}\right.$ & $\left.\begin{array}{l}175 \\
168 \\
138\end{array}\right\}$ & $\mathrm{CaSO}_{4}$ 使 \\
\hline
\end{tabular}

それにすかかわらず, これらの外観，味は簡単に区別 できない。

たへ方にる問題がある。乾魯類の骨ごと食べるのと， 肉のみ食べるのとでは，Ca，P の揁取量はまつたくちが 5。頭をたべれば Ca の掑取量はさらにふえる。乾魚の 頭をたべたかど5か，骨を残したか否か…...., 栄膯調査 にはこれはあらわれていない。しかし無譏質の場合はそ れが最重要なボイントである。残忩なことに現在の食品 成分表の内容や栄調查の方法か，無幾質を重点におい ていないために，同一食品の質によるこのよ5な大きな 開きは，そのままに放置されたかたちとなつている。

\section{(ii) 摄取量の個人差}

無機質含量が食品によつてかたよつた大小を示してい ること，すなわち一部の特殊な食品が異常に高い無機質 含量を示していること，およびそれらが概して安佂な食 品であることは，食事の種類による無幾質掑取量の個人 羑を大きくする因となつている。

あえて強化食品に传存することなくとす，例えばにわ とりの肝ぞう $20 \mathrm{~g}$ は, 1 日の $\mathrm{Fe}$ 必要青を十分満たす ことができようし，にぼし $10 \mathrm{~g}$ は現在の $\mathrm{Ca}$ 椇取総量 の3/4 にあたるものを供給し得る。

牛乳を例にとれば，その1合が供給する各栄素量は 第 12 表のごとくで, それを栄葆調査による 1 日平均掑 取里に対する\%で示した。右桐で，Ca の值の異常な

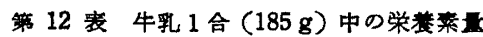

\begin{tabular}{|c|c|c|c|}
\hline & & 1 合中の成分 & 挴取量*との比(\%) \\
\hline 熟 & 量 & 109 & 5 \\
\hline たんば & $(\mathrm{g})$ & 5.6 & 8 \\
\hline 脂 & 筫 1 & 5.9 & 29 \\
\hline 炭水仡 & 物 11 & 8.3 & 2 \\
\hline $\mathrm{Ca}$ & $(\mathrm{mg})$ & 185 & 55 \\
\hline $\mathbf{P}$ & $" \prime$ & 160 & 12 \\
\hline $\mathrm{Fe}$ & " & 0.2 & 1 \\
\hline V. A & (I.U.) & 185 & 1 \\
\hline V. $B_{1}$ & $(\mathrm{mg})$ & 0.06 & 5 \\
\hline V. $B_{2}$ & $"$ & 0.28 & 42 \\
\hline V.C & $"$ & 1 & 9 \\
\hline
\end{tabular}

* 国民栄養調查全国平均 (昭和 30 年)

高さが目だつている。即を毎日 5 個などとい5のとちが つて，牛乳 1 合を毎日規則的に飲むことは，最近普通に 見られる例である。第 12 表によると，そうした習馈の 人は，それたけけで他の人と平均 $\mathrm{Ca}$ 撕取量の 1/2 の差が あることになる。

一般人の 5 割よけいに熱量をとる場合を考えれば，無 機質の特殊性がはつきりするであろう。

(iii）個人差はどの無機質にはげしいか

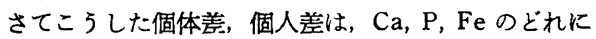
多いのであろうか。

上に分析例を揭げたかぶの葉，しらすぼし，とうふの 場合， $\mathrm{Ca}$ の個体差はいずれる $\mathrm{P}$ より大きかつたが，こ れはかなり一般的にあてはまる現象である。水の例す Ca だけの問題であつた。Ca の主要給源が，豆類は別と して, 野菜類, 骨ごとの魚類, 水といつたような, るつ とも個体差の大きい食品であるのに対し，P の大部分の 給源か，湸類, 豆類, 獸鳥围肉類のごとき，本質的に成 分変動の寸くない食品に限られていることは，P·の総掑 取量が Ca の倍以上あることと相まつて，よけいにPの 摄取量の個人差をすくなくする結果になつている。

$\mathrm{Fe}$ の給源は比較的ばらばらではあるが豰類が大部分 で,あとの食品も主要給源にはむしろ個体差がすくない。 たた異常に $\mathrm{Fe}$ 含量の多い食品を時にとる可能性と，混 大の問題から，個人差は「栄婘調査の結果よりも多くな る方向にのみ」かなりの大きさを示す。

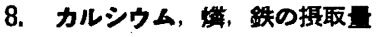

以上各項にわたつてのぺてきたことを，一㲠表にして 第 13 表に集計した。この集楌から得られる結論は第 2 図によつて端的に示される。日本人の無機質掑取】の特 質とされていた， $\mathrm{Ca}$ の大欠乏， $\mathrm{P}$ の大過剩とい5観念 は，いくらかです是正される時期に来ていると見ね代な 
第 13 表 摄取旦火対する硣修正

\begin{tabular}{|c|c|c|c|c|}
\hline 項目 & & $\mathrm{Ca}$ & $\mathbf{P}$ & $\mathrm{Fe}$ \\
\hline 1 & 国民栄䓹調查の数值（全国） & 340 & 1370 & 14 \\
\hline $2-\mathbf{i}$ & 魚 介類 の 補 正 & 20 & - & - \\
\hline $2-\mathrm{ii}$ & 清 物 類 の 補 正 & 10 & 20 & - \\
\hline $3-i$ & しょ 5 油の補 正 & 15 & 50 & 1 \\
\hline 3-ii & 海 草類 の補 正 & 10 & - & - \\
\hline 4 & 水 & $\begin{array}{c}50 \\
(20 \sim \\
200)\end{array}$ & - & - \\
\hline $5-i$ & 米の湖洗による損失 & -5 & -270 & -1 \\
\hline \multirow[t]{2}{*}{$5-\mathrm{ii}$} & 麦,野菜, 魚等の調理の損失 & -5 & -120 & - \\
\hline & 計 & 435 & 1050 & 14 \\
\hline 6 & 食品 外混 入 & - & - & + \\
\hline 7 & 摄 取 量 の 個 人 差 & & & \\
\hline \multirow[t]{2}{*}{$\cdot$} & a. +の方向のめの & 大 & 小 & 大 \\
\hline & b. 一の方向の の & 大 & 小 & 小 \\
\hline
\end{tabular}

第2因 $\mathrm{Ca}, \mathrm{P}, \mathrm{Fe}$ 摄取量
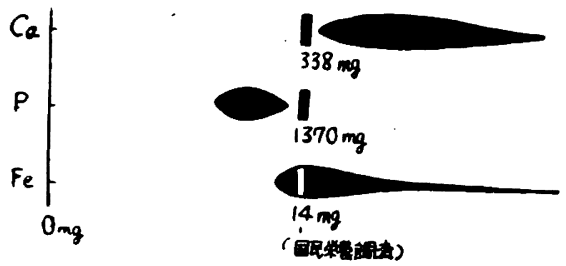

るまい。Ca は相かわらず不足ではあるが，その度合は 今まで考えられていたほどひどいるのではない。Pに至 つては,必要量ぎりぎりの線を上下しているにすぎない。 莺にす考えられなかつたPの不足とい5現象が，どこか で，たとえば成長期の少年などで，はたして絶対に起つ てはいないであろろか。

$$
\text { マンガン・銅・亜鉛 }
$$

微釷金属元素として普通にミネラル刻にはいつている のは, マンガン, 銅, 㕵鈶、 コバルト, モリブデン等で ある。

本稿ではその5ちで比較的椇取量の多い, マンガン， 銅，覀鉊について考えてみたい。コバルトとモリブデ: に関しては資料にそしく，撌取量もさたかでない。たた 以上三つの元素に比して，摄取量がす 5 一つない二つ 下の単位にあることはまちがいない。

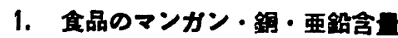

食品のマンガン，銅，亜鉛含量については，近年外国 では相当数の報告があり，わが国でもわずかなかららデー タがあり, 本誌です後藤氏による報告(17)(18) が行われて
いる。䈉者もここ数年日本全品の $\mathrm{Mn}, \mathrm{Cu}, \mathrm{Zn}$ を測定程， しており，それらを綜合して食品群别会士をるとめた結 果は第 14 表のよ5になる。一般に（何となく）食品の 微正金愿含专には，非常に大きな個体差があると考えら

第 14 表 食品の $\mathrm{Mn}, \mathrm{Cu}, \mathrm{Zn}$ 含旦（推定）

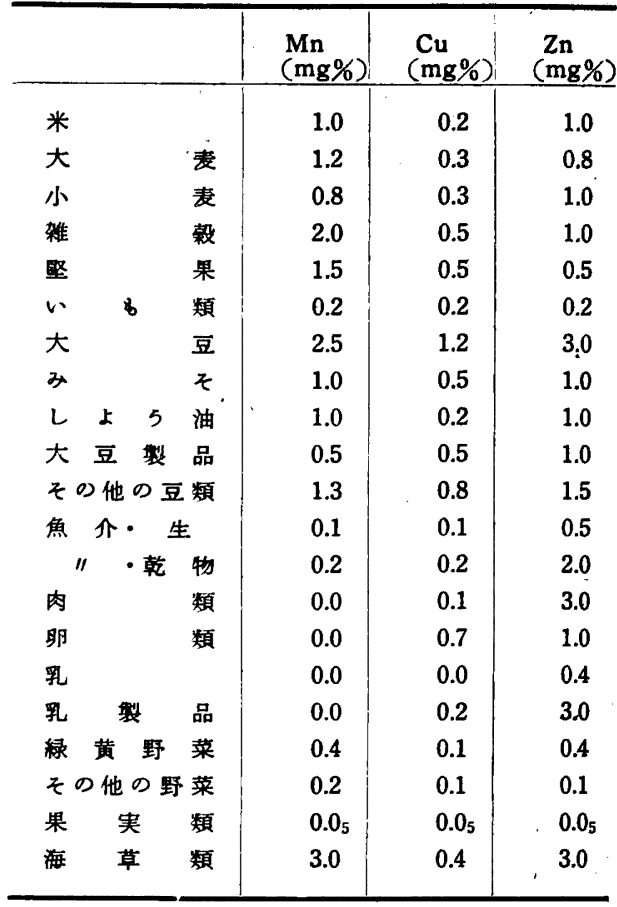

れている。多くの場合たしかにそれは本実であるか，そ の差は決して無制限に大きなるのではない。時には米の $\mathrm{Zn}$ 合量のごとく, Fe はすちろん $\mathrm{Ca}$ よりす個体差の すくない例さえある(20)。第 14 表の数值は平㚬值として まずあやまりのないあのと考えてよい。

概観すればは，Mnは動物体にはきわめてすくなく， 、植物体ことに暿類，豆類等の種烣，海草等に多い。著書 やバンフレットに, Mn はじやがいる，牛乳に多いなど と記俴したものを散見するが，これはまつたくのあやま りである。

$\mathrm{Cu}$ は食品群别にみると，特別何に多いということな く，比較的まんべんなく含まれている。ただし個々の食 品によつては, いちじるしく $\mathrm{Cu}$ 含岳の高いすの, たと えば甲教類や貝類の一部，動物の肝䑏などがあり，また

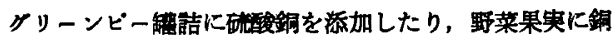

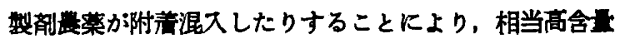
のあのを生ずることに注意を要する。ぶど5酒の $\mathrm{Cu}$ 含 正がかなり高いことはめずらしくない。 
Zn は Mn と逆に野物页に多い。Zn の秴源を野莱と みなしている著劃が多いが、これるあゃまりで，植物体 ではやはり豆類，贱類，海草に多い。注目すべきは $\mathrm{Zn}$ 含业は一般的にかなり高いことであつて，米や乳，缺肉 では常に Feよりも Zn の方が多い。

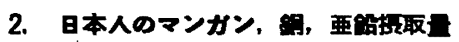

第 14 表の数值を基淮にして，国民栄街調查の結果を 借りれば，大まかに日本人のこれら3元素椇取量を算出 することができる。算出に際しては， $\mathrm{Ca}, \mathrm{P}, \mathrm{Fe}$ の項で 行つたよらな紐かい考察を行らすべあなく、わずかに米 の䖲洗による Mn の損失を $30 \%$ と拀いて補正したた けであつた。

第 15 表にはその值を，外国人の場合と比較するため に; 米国人の栄責調査の数字をかりてその掫取量を計算

第 15 表 食品群別 $\mathrm{Mn}, \mathrm{Cu}, \mathrm{Zn}$ 掫取量 $(\mathrm{mg})$

\begin{tabular}{|c|c|c|c|c|c|c|c|c|}
\hline & & & \multicolumn{2}{|c|}{ 日 } & 人 & * & 国 & 人 \\
\hline & & & $\mathrm{Mn}$ & $\mathrm{Cu}$ & $\mathrm{Zn}$ & $\mathrm{Mn}$ & $\mathrm{Cu}$ & $\mathrm{Zn}$ \\
\hline 摋 & & 類 & 4.79 & 1.10 & 4.67 & 1.70 & 0.63 & 2.13 \\
\hline$w$ & 8 & 類 & 0.15 & 0.15 & 0.18 & 0.13 & 0.13 & 0.13 \\
\hline 豆 & & 類 & 0.92 & 0.54 & 1.09 & 0.38 & 0.19 & 0.38 \\
\hline 果 & 実 & 類 & 0.03 & 0.02 & 0.02 & 0.12 & 0.12 & 0.12 \\
\hline 野 & 菜 & 類 & 0.71 & 0.16 & 0.60 & 1.24 & 0.31 & 1.24 \\
\hline 内 & & 䅡 & 0 & 0.01 & 0.31 & 0 & 0.20 & 6.03 \\
\hline 卵 & & 頻 & 0 & 0.07 & 0.10 & 0 & 0.40 & 0.57 \\
\hline 魚 & 介 & 類 & 0.05 & 0.09 & 0.55 & 0.01 & 0.01 & 0.14 \\
\hline 甩 & & 類 & 0 & 0 & 0.06 & 0 & 0.40 & 3.95 \\
\hline & 郃 & & $6.7^{*}$ & 2.1 & 7.6 & 3.6 & 2.4 & 14.7 \\
\hline
\end{tabular}

し、これを併記した。（米国を特に選んたのは，米国の食 形態が日本と最す強い対照をなしている点, すなわち殻

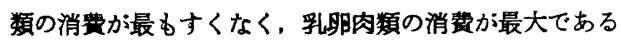
点にるとついた。したがつて外国ですフランス，さらに はイタリア等は両者の中間に位置することになろう。)

第 15 表のほか, お杂からの Mn を忘れることはで きない(价こ机は茶葉には非常に大量の Mn を含むる のか多く、これから少量の Mn かi浸出されてくること にもとつく。筆者の実験です一般に条（紅茶をふくむ） 骎出液の $\mathrm{Mn}$ は, $0.1 \sim 0.2 \mathrm{mg} \%$ に達し, 日本人の莱の

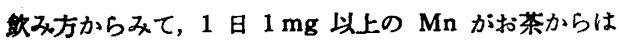
いつていることになる。この補正を加えると日本人の Mn 摄取量は一応 $7.4 \mathrm{mg}$ と考えてよいであろ5。コー ヒーを多用して茶をあまり领まね米国人の場合はこのこ とがない。

両者を比較すると，意外に大きな差がある。日本人は． 米人に比し， Mn は約 2 倍を摄取し，Cu はほぼ变りな
く，Zn は逆に半分しかとつていない。動物性食品の多 少を如矨に示す結果になる。

\section{3. ミネラル绪の効用}

さて以上の結果は, 市肘ミネラル阂中の $\mathrm{Mn}, \mathrm{Cu}, \mathrm{Zn}$ 量とどらいう関係にあるたろらか。健康維持のためには 1 日 1 錠とい51錠中のこれらの元素量は，薬によつて すこしずつ虺つている。第 16 表にはその5ち 3 種類を 例示し，米国の代表的幣㓮 1 種をむ併記した。同じ表に， 現在これら 3 元素の 1 日要求量とされているすの（諸説 正確には一致していない)を揭げた(22)。

第 16 表 摄取量とミネラル唷の $\mathrm{Mn}, \mathrm{Cu}, \mathrm{Zn}$ 量

\begin{tabular}{|c|c|c|c|c|c|c|c|}
\hline & \multicolumn{3}{|c|}{ 掑 取 } & \multicolumn{4}{|c|}{ ミネラル削1錠中の含量 } \\
\hline & 日本人 & 米国人 & 摄 取 & $\mathrm{A}$ 社 & B 社 & $\mathrm{C}$ 社 & (社) \\
\hline $\mathrm{Mn}$ & 7.7 & 3.6 & 4 & 0.50 & 0.25 & 0.65 & 5.0 \\
\hline $\mathrm{Cu}$ & 2.1 & 2.4 & 2 & 0.75 & 0.5 & 0.38 & 0.25 \\
\hline $\mathrm{Zn}$ & 7.6 & 14.7 & 15 & 0.50 & 0.28 & 0.45 & 1.5 \\
\hline
\end{tabular}

偶然とい5か，米人について計算した䀸取量は，いず れもちよ 5 ど要求量をみたす程度であり，強いていえば Mn が不足の可能性がある。これに対して日本人の数值 は, Mn は過剩, $\mathrm{Cu}$ はちよ 5 ど, $\mathrm{Zn}$ は要求量の $1 / 2$ を示している。

Zn はたしかに動植物界に広く分布してはいるが，要 求量すまた相当に大きい。すし $\mathrm{Zn}$ が日本人に真に不足 しており、それを補5ためのミネラル剤であるならば, 1 日 $0.3 \sim 0.5 \mathrm{mg}$ の $\mathrm{Zn}$ は一体どれたけの意味をるつ とい5のであろ5か。

Mn は一応過剩であり，これをさらに葲品としてとる 必要はなさそらである。一歩ゆずつて妊座婦，子児など に対していくらか必要たとしても，0.2〜0.5 mg の量が どれだけ役立つであろうか。

$\mathrm{Cu}$ は全椇取要, 求量ともに小さく, ために薬品と してのすじはいちばん通つているか，なお大同小異のそ しりをまねかれない。

こ5見てくると筆者は，日本のミネラル阂は，一体何 を基準にしてそのドーゼを決めてあるのか，あやしまざ るを得ない。微量金属の必要性そのものにかかる根本的 な䛾論はおいても，米国の製品には米国人の头情にもと つく一応の根拋があるよ5に見える。Mn の不足を補 意味で大量の Mn を加え, 要求量をみたしている $\mathrm{Zn}$ と $\mathrm{Cu}$ は，少量でしかす掑取量に応じて $\mathrm{Zn}>\mathrm{Cu}$ の関係を 保たせていることは，米国人にとつて正当な方法であろ 5 。

日本の製品では事情を異にしている。米国の Mn に (231) 
代るものが日本ではZn $\mathrm{n}$ であるにすかかわらず, その $\mathrm{Zn}$ が減量されている。おそらく，Mn と Zn は植物界こと に野菜に豊富に分布しているとい5架空の「伝説」が， わざわいをなしているのではあるまいか。

ミネラル剤をまじめに考えるならば，すくなくとも日 本人のミネラル䀸取量をはつきりと畋識した5えで，最 適の栄整補給の途を講じてほしいと策者は考える。ミネ ラルの数を競 ら前に, その本質に目をむけるべきではな いだろらか。

\section{交献}

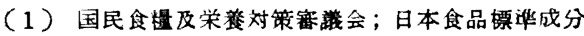
表 (第一出版) (1950)

（2）総理府盗源調查会; 改倍日本食品摽制成分表 (第一出版) (1954)

（3）厚生省; 国民栄養の現状 (1956).

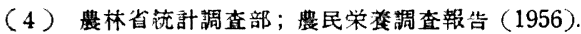

（5）木村；本誌 5，176 (1952).

（6）川上・相沢・槽原；本殸 6, 117 (1953).

（7）纯藤；本誌 8,110 (1955).
(8) 半谷; 日化, 74,544 (1953).

(9) 小林; 農学研究, 43,1 (1955).

(10) 同上, 4127 , (1953).

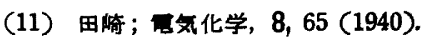

（12）佐伯他; 栄娄研究所報告 9，第 1 昌 (1936).

（13）神谷；本誌 9, 50 (1956).

（14）错藤；本婄 6, 54 (1953).

(15) 同上 6, 213 (1953).

(16) 土瘫・越野；本誌 5, 109 (1952).

（17）後藤；同上 7, 69 (1954).

(18) 同上, 8, 158 (1955).

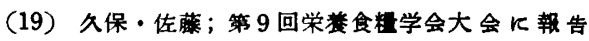
(1955).

（20）久保；日化，投称中。

(21) Monier-Williams; Trace Elements in Food (Chapman \& Hall Co.) p. 307 (1950).

（22）中川・二国・吉川；栄巷学（松村）第 7 章（蝴 合春店) (1955).

（食粠研究所）

堆マウスに対する genistin の作用

クロバーから分離した genistin, 4'. 5. 7. trihydroxyisoflavone の卵胞ホルモン作用を有することが知ら れてから，食物の䀦抱ホルモン样作用のある化合物の分 布状態又は生理的作用についての研究が行われて来た。 大豆油食の中の畉抱ホルモン作用は genistein の glucoside である genistin の存在によることが明かにされ た，著者等の研究空でも大豆油の genistin を食物の $0.2 \%$ \%まぜてマウスに食わせると出生仔数が少いこと を認めた、この度は雄マウスに $9,18,36,72 \mathrm{mg} 1$ 日 量として与えた所，生長率は genistin の照の対数と逆
相関にあり，又睪丸の重量をへらす作用があるし，大量

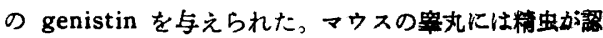
められなかつた。体重，覃丸発育に対する genistin と stibbestrol との相違からみると, genistin は本来眃胞 ホルモン作用のあるるのと思われない。

Effect of genistin on growth and developement of the male mouse. G. Matrone, W. W.G. Smart Jr., M. W. Garter, V. W. Smart and H. W. Garren. J. Nutr. 59 : 235, 1956.

（野䗁幸 久) 